\title{
Morphological features of adults and nymphal instars of Coloceros species (Phthiraptera: Insecta) recovered from Collared-dove Streptopelia decaocto
}

\author{
Padam Singh \\ Department of Zoology, Government Raza Postgraduate College, Rampur-244901 \\ (U. P.), India \\ Ghazi Khan \\ Department of Zoology, Government Raza Postgraduate College, Rampur-244901 \\ (U. P.), India

\section{Surendra Kumar} \\ Department of Zoology, Government Raza Postgraduate College, Rampur-244901 \\ (U. P.), India \\ Nidhi Gupta* \\ Department of Zoology, Government Raza Postgraduate College, Rampur-244901 \\ (U. P.), India \\ ${ }^{*}$ Corresponding author. E-mail: dr.nidhigpta@gmail.com

\begin{abstract}
The present report furnishes information on the morphological features of specimens of Coloceros species collected from Collared-dove Streptopelia decaocto in district Rampur. Three nymphal instars of Coloceros sp. can be differentiated by the number of setae present on the postero-lateral angles of pterothorax and abdominal segment six to ninth in addition to nature of sclerotization and abdominal segmentation.
\end{abstract}

Keywords: Avian louse, Chaetotaxy, Coloceros, Ischnocera, Phthiraptera

\section{Article Info}

DOI: 10.31018/jans.v10i4.1853

Received: August 8, 2018

Revised: November 22, 2018

Accepted: November 30, 2018

\section{How to Cite}

Singh, P. et al. (2018) Morphological features of adults and nymphal instars of Coloceros species (Phthiraptera: Insecta) recovered from Collared-dove Streptopelia decaocto. Journal of Applied and Natural Science, 10(4): 1341-1344

\section{INTRODUCTION}

Lakshminaryana (1979) listed seven phthirapteran species (e.g.Companulotes bidentatus scopois, Coloceros piageti Johnston and Harrisson, Coloceros sofloticus Eichler, Columbicola columbae Linne, Columbicola confussimus Eichler, Hohorstiella modestum Ansari and Turturicola salimalii Clay and Meinertzhagen) from the Collared Dove Streptopelia decaocto and Streptopelia decaocto decaocto. However, Price et al. (2003) recognized only four ischnoceran species e.g.Coloceros hilli Bedford, Coloceros piageti Johnston and Harrisson, Columbicola bacillus Giebel and Turturicola salimalii Clay and Meinertzhagen from Streptopelia decaocto and two species e.g. Bonomiella conci Eichler and Hohorstiella modesta Eichler from Streptopelia decaocto decaocto. Bansal et al. (2010) described a new species of genus Hohorstiella from Streptopelia decaocto decaocto.

Certain workers have provided useful information on the diagnostic characterstics of three nymphal instars and morphology of different avian lice (Clay, 1958; Modrzewska and Zlotorzycka, 1987; Mey, 1994, Price and Hel- lenthal, 1996; Smith, 2000; Beg et al., 2004; Agarwal, 2011 and Singh et al. 2013, 18). The present report furnishes information on the Chaetotaxy of three instars of nymphs of Coloceros species recovered from Streptopelia decaocto.

\section{MATERIALS AND METHODS}

During present studies specimens of genus Coloceros were collected from Collard-dove Streptopelia decaocto were subjected to LM studies. The three nymphal instars of avian lice resemble to each other to a greater extent and are often difficult to differentiate. The adults and three nymphal instars of Coloceros species recovered from Streptopelia decaocta were subjected to maceration $(10 \% \mathrm{KOH})$, Acetic acid treatment $(10 \%)$, dehydrated (ethanol series), clearing (Clove oil) and mounting (Canada Balsam) according to technique given by Palma (1978). Permanent preparation of adults and nymphs were subjected to microscopy (under Trinocular Microscope) and drawing with the help of Camera Lucida drawings. The literature offered by Tendeiro (1973) was used for taxonomic identity of specimens. 


\section{OBSERVATIONS}

Adult morphology (Plate I: Photo 1-6) :

Head (Plate I: Photo 1, 4): Head alike in both sexes, slightly broad than long, frons parabolic, smooth; marginal carina width medium to thick, indentations in marginal carina deep and well developed; ventral carina thick and well chitinized; preantennal and dorsal postantennal dorsal sutures fused, forming a large pentagonal area with concavous antero-externe margins and the vertex reaching the proximity of the occipital margin; head very wide at the temporal angles; preantennal region short; postnodal seta long, reaching the middle temple; temporal angles relatively thick and pointed; marginal bands wide; clypeal margins circular; medial dorsal groove absent; mandibles sharp; oesophageal gland and hypopharynx well developed; antennae long, with the article III not much curved inwards at the proximal third part, rather shorter than II, article $\mathrm{V}$ with a little internal basal protuberance; temporal carina forms complete thickened band.

Thorax (Plate I: Photo 2, 5): Prothorax angular, lateral margin smooth; pterothorax trapezoidal with smooth lateral margin, ventral pterothoracic setae absent, two distinct setal pairs on both sides of postero-lateral margins of pterothorax present, median setae on posterior margin of pterothorax small; pterothorax and abdominal segment II separated; mesofurcal pit small and poorly develoved; legs well developed with highly pigmented coxal plates and marginal bands.

Abdomen (Plate I: Photo 3, 6): Oval shaped, wide, with the maximum width at the segment IV; nine distinct segments, Abdominal segment II not deeply embedded dorsally within abdominal segment III, margins of abdominal segment II partially enclosed by pterothorax and abdominal segment III; dorsal medial division of abdominal segments present, tergal plates not fused; pleural bands widened, with well delimitated chitinous reinforcement and mainly in females with curved expansions, longer from the $\mathrm{V}$ segment to the VII; lobes of posterior abdominal segment subconcavous laterally and rounded in the middle; polygonal marks absent; One long tergal seta present on IV to $\mathrm{VI}$ and two long seta present onVII and VIII segment and one micro tergal marginal seta present on VI and VIII segment; one seta present on VI and IX segment at ventral side.

Male Terminalia (Plate I: Photo 6): Male abdominal segment IX composed of prominent lobe extending beyond natural margin of abdomen; weakly bilobed seta bearing plate embedded partially within abdominal segment IX.

Female Terminalia (Plate I: Photo 3): Simple; vulval margin fringed by one row of setae; single setaon both sides on lateral edge of vulval margin present.

Male Genitalia (Plate I: Photo 6): Male genitalia typical, with the basal plate long, widened in front and narrowing hardly at the middle, forming two long and slender posterior branches; length (assuming apical tip) extend into abdominal segment IV; paramears short and the genital sac with not much coarse denticulations.

Nymph morphology (Fig. 1 A-D) :

First instar nymph (Fig. 1 A): Oval in shape, white in colour,measur $0.73 \mathrm{~mm}$ in length and $0.31 \mathrm{~mm}$ in breadth. Head long as broad, preantennal region rounded, post-antennal region slightly trapezoidal; widest at temporal angles; ventral carina thin, fused with clypeal margins; antenna four segmented, III segment triangular while terminal segment long and narrow; eyes not seen; coni absent; post antennal nodus rounded; cutting edges of mandibles not sharp, less pigmented; oesophageal gland and hypopharynx feebly sclerotized; temple trapezoidal, slightly pointed at postero-lateral angle with one long seta; temporal carina thin; gular plate and other structures remain unpigmentedand unsclerotized and therefore, are not clearly visible. Prothorax angular, lateral margins straight, posterior margin slightly convex, one seta present at postero lateral angle; pterothorax large than prothorax, lateral margin smooth, posterior margin slightly pointed on abdomen, devoid of seta; legs well developed, first pair of legs shortest, claws of second and third pair of legs are longer and sharper than first pair of legs; coxal plates less pigmented. Abdomen oval; nine segmented, segmentation not so

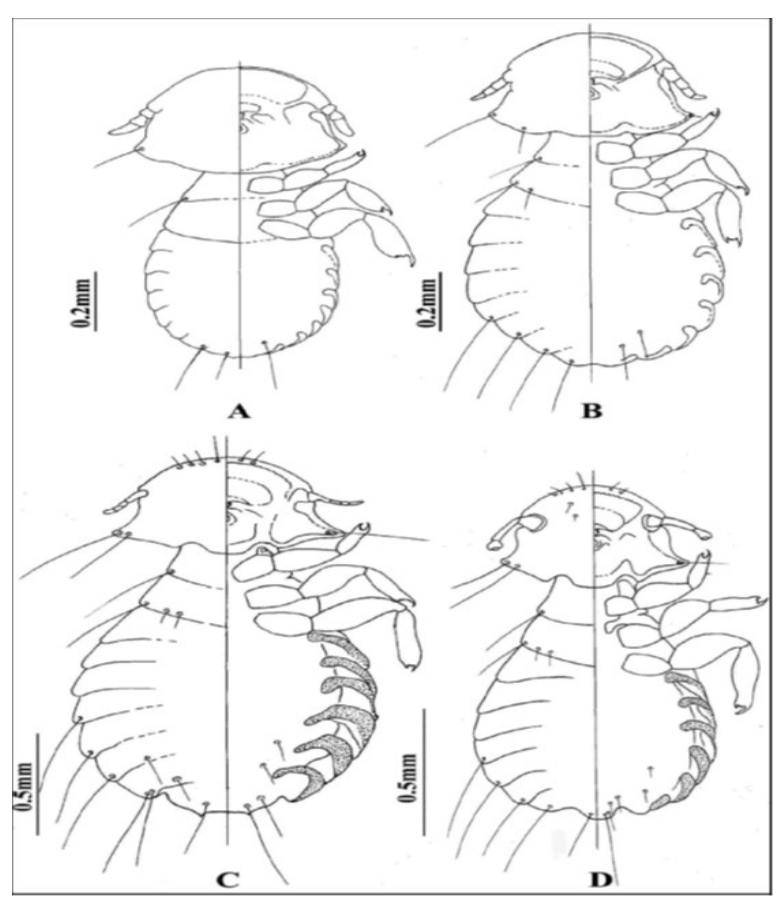

Fig. 1 (A-D). Dorso-ventral aspects of three instars nymphs of Coloceros sp. A. First instar nymph; $B$. Second instar nymph; C. Third instar nymph (female); D. Third instar nymph (male). 
Singh, P. et al. / J. Appl. \& Nat. Sci. 10 (4): 1341-1344 (2018)

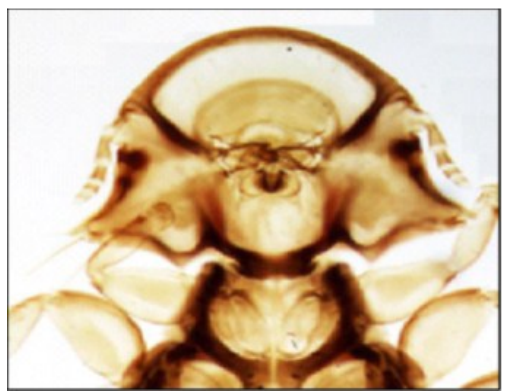

1. Head region $X 63$

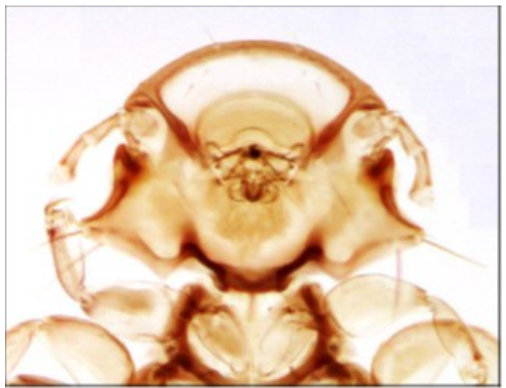

4. Head region $X 50$

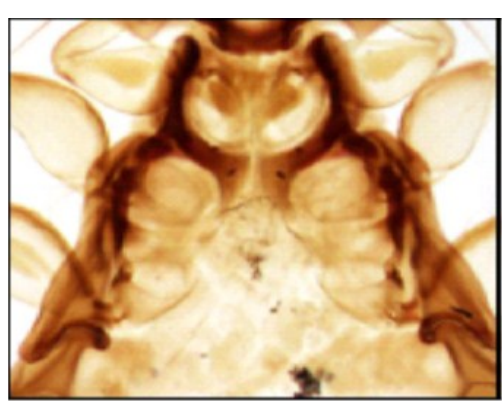

2. Thoracic region $X 63$ Coloceros sp., Adult Female

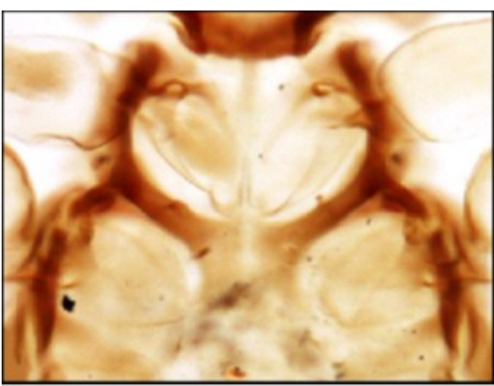

5. Thoracic region $X 107$ Coloceros sp., Adult Male

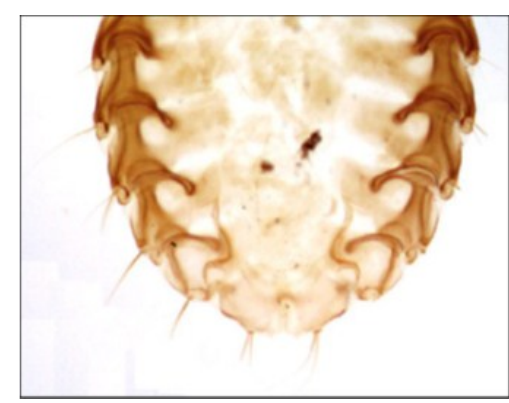

3. Abdominal region $X 45$

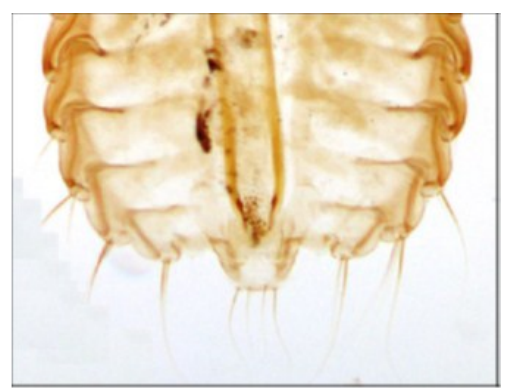

6. Abdominal region $X 50$

Plate 1: Showing enlarge view of Head, Thorax and Abdomen region of Adults (Male and Female) of Coloceros sp.

clear; tergal margins feebly seen, sternal plates absent, pleural bands brownish, broad at top, one setapresent on VIII and IX segment dorsally and one seta present on VIII segment atventral side.

Second instar nymph (Fig. 1 B): The second instar nymph resembled the first instar nymph in general characters (measures $0.83 \mathrm{~mm}$ in length and $0.42 \mathrm{~mm}$ in breadth) but more sclerotized and well pigmented. Head iwas less longer than broad, widest at temporal angles; ventral carina thicker than that of first instar; clypeal ring more prominent; mandibles well developed, cutting edges of mandibles brownish; oesophageal gland and hypopharynx developed; antenna long, segmentation clear; preantennal nodes well seen fused with postantennal nodus, temples well developed, trapezoidal, pointed at postero-lateral angle with one long, one short seta present at dorsal and ventral side, respectively; posterior margin of temples not straight with one short seta dorsally; temporal carina thick at occipital and lateral margins. Prothorax same as in first instar nymph in respect of shape and chaetotaxy, while pterothorax became more pointed on abdomen with one seta on postero-lateral angle and one marginal seta; legs well developed with pigmented coxal plates. Abdomen quite elliptical in shape with nine distinct segment; tergal margins clear, not fused in middle; sternal plates not seen; pleural bands more chitinized, dark, thick and broad anteriorly, prominent, posterior end continue in succeeding segment, devoid of seta; one long marginal tergal seta present on VI, VII, VIII and IX abdominal segments; one nor- mal sternal seta present on VIII and IX abdominal segments, on each side.

Third instar nymph (Fig. 1 C and D): The third instar nymph resembled the second instar nymph in general characters. But for the first time sexual dimorphism, in the characters of the first two antennal segments, became evident at this stage. This character enabled the separation of nymph into two types, those with the antennae with more or less prominent protuberance, formed by the articles III and IV, which after the third moult produced the male and those in which the first antennal segment was normal and which after the thirdmoult were destined to produce the female. Therefore, the former was called the male nymph and the latter the female nymph. Other characters in which these differed from the second instar and approached the adult stage were increase in size, enlargement of the pigmented areas on the head, thorax, legs and abdomen. The male nymph measured $1.04 \mathrm{~mm}$ in length and $0.52 \mathrm{~mm}$ in breadth, whereas the female nymph measured $1.24 \mathrm{~mm}$ in length and $0.63 \mathrm{~mm}$ in breadth. The head with dark chitinized carina and clear clypeal markings; clypeal region clear with two short setae on dorsal side; frontal region with four and twosetae on dorsal and ventral side respectively; temporal chaetotaxy same as in second instar nymph, gular plate now feebly visible, devoid of setae. Prothorax posterior margin slightly pointed on pterothorax, its anterior marginlied under the occipital margin of the head to form a characteristic neck; pterothorax with two marginal setae and one 
long seta on posteo-lateral corner. Head andthoracic chaetotaxy same in both sexes. Abdomen pear shaped, posteriorly truncated in female with clear nine distinct segments; tergal posterior margins clear; pleural plates thick and pleural bandexpanded internally. Abdominal chaetotaxy differed in both sexes.

Male (Fig. 1 D): One long tergal seta present on $V$ to IX segment and one micro tergal marginal setapresent on VI and VII segment; one seta present on VI and VII segment and two setae present on VIII segment at ventral side; one long and one short seta present on terminal end.

Female (Fig. $1 \mathrm{C}$ ): One long tergal seta present on $\mathrm{V}$ to VII and two long setae present on VIII segmentand one micro tergal marginal seta present on VII and VIII segment; one seta presenton $\mathrm{VI}$ and $\mathrm{IX}$ segment at ventral side.

\section{DISCUSSION}

Tendeiro (1973) made most valuable contribution on the taxonomic status of the genus Coloceros. Accordingly genus Coloceros is characterized by sexually dimorphic antennae, relatively elongated legs, abdominal shape clariform in males and oval or elliptic in females, maximum width at the edge of segment 3 and 4, narrow pleural bands (with more or less widened, well delimilated, chitinous reinforcement, glabrous female genital opening and presence of gonapopophyses (generally with 1-4 spinous setae). Two species of the genus $\mathrm{Col}-$ oceros have been listed from S. decaocto (e.g. C. piagetiand $C$. hilli). However, the specimens of genus Coloceros collected during present studies exhibited slight difference in chaetotaxy and in the measurements from the aforesaid two species. Exact taxonomic identity of the specimens presented some confusion and dispute among the phthirapterists consulted for the purpose. Hence, for present description, species name is not being assigned and specimens are being referred as Coloceros sp.

The second instars of Coloceros sp. can be differentiated from the first instars on the grounds of better sclerotization, abdominal segmentation and appearance of two setae on postero-lateral angles of pterothorax and development of seta on sixth and seventh abdominal segments. Likewise, third instars can be seperated from second instars due to appearance of two setae on clypeal margins, development of two marginal and one long seta on the postero-lateral angle of pterothorax and the appearance of microsetae and pleural setae on abdominal segment sixth to ninth.

\section{Conclusion}

The nymphal instars of avian Phthiraptera resemble to each other to a greater extent (except difference in size and sclerotization). However, first, second and third instar nymphs of Coloceros sp. (infesting Collard-dove Streptopelia decaocta) can be distinguished on the basis of number of setae on pterothorax and abdominal segment six to ninth.

\section{ACKNOWLEDGEMENTS}

Authors are thankful to Principal, Govt. Raza $P$. G. College, Rampur (U.P.) for laboratory facilities.

\section{REFERENCES}

1. Agarwal, G. P., Ahmad, A., Rashmi, A., Arya, G. Bansal, N. and Saxena, A. K. (2011): Bio-ecology of the louse, Upupicola upupae, infesting the Common Hoopoe, Upupa epops., J. Insect Sci. 11(46): 1-9.

2. Bansal, N., Singh, P., Ahmad, A., Arya, G. and Saxena, A. K. (2010): A new species of Hohorstiella (Menoponidae: Phthiraptera) from Indian Ring Dove, Streptopelia decaocto decaocto (Columbiformes). Entomon, 35(3): 183-190

3. Beg S., Singh, S. K. , Gupta, N., Kumar, S. and Saxena, A. K. (2004): Morphometric variability of five species of lice (Phthiraptera) infesting common crows. J. Exp. Zool. India, 7(2): 213-228.

4. Clay, T. (1958): Revisions of Mallophaga genera Degeeriella from the Falconiformes. Bull. Br. Mus. Nat. Hist. Entomol., (London), 7: 123-207.

5. Lakshminaryana, K. V. (1979): A synoptic list of Mallophaga. Rec. Zool. Surv. India, 75: 39-201.

6. Mey, E. (1994): Beziehungen Zwischen larvemorphologie und systematik der adultibei den vogelIschnozeren (Insecta, Phthiraptera, Ischnocera). Mitt.Zoologisch. Mus., Berlin, 70: 3-84.

7. Modrzewska, M. and Zlotorzycka, J. (1987): Studies on morphology of nymphsof selected Amblycera and Ischnocera (Mallophga). Pol. Pismo. Entomol.,57: 657 -672 .

8. Palma, R. L. (1978): Slide-mounting of Lice: a Detailed Description of the Canada Balsam Technique. The New Zealand Entomolt. 6(4): 432-436

9. Price, R. D and Hellenthal, R. A (1996): Taxonomic importance of first instarchewing lice (PhthirapteraTrichodectidae) from pocketgophers (Rodentia :Geomydae). Ann. Entomol. Soc. Am., 89: 570-578.

10.Price, R. D., Hellenthal, R. A., Palma, R. L., Johnson, K. P. and Clayton, D. H.(2003): The chewing lice: World checklist and biological overview. Illinois Natural History Survey special Publication, 24: $X+501 \mathrm{pp}$.

11.Singh, P., Aryra, G., Bansal, N. and Saxena, A. K. (2013): Chaetotaxy of an amblyceran ring dove louse, Hohorstiella rampurensis (Phthiraptera). Biojpournal. 8(2): 01-07.

12.Singh, P., Ahmad, A., Khan, G. and Gupta, N. (2018): Morphometric variability of three species of lice (Phthiraptera) infesting Collard-dove, Streptopelia decaocto (Aves: Columbiformes). Biojournal (In Press).

13.Smith, V. S. (2000): Basal ischnoceran louse phylogeny (Phthiraptera: Ischnocera: Goniodidae and Heptapsogasteridae). Syst. Entomol., 25: 73-94.

14.Tendeiro, J. (1973): Estudossobreos Goniodideos (Mallophaga: Ischnocera) dos Columbiformes, XIVGenero Coloceras Taschenberg, 1882. Universidade De Lourenco Marques. 